\title{
Paper Development of Actuarial E-learning Based on Android Applications
}

\author{
$1^{\text {st }}$ Suherman \\ Mathematics Department, Faculty of \\ Mathematics and Sciences \\ Universitas Negeri Padang \\ Padang, Indonesia \\ suherman@fmipa.unp.ac.id
}

\author{
$2^{\text {nd }}$ Defri Ahmad \\ Mathematics Department, Faculty of \\ Mathematics and Sciences \\ Universitas Negeri Padang \\ Padang, Indonesia \\ defri_math@fmipa.unp.ac.id \\ $4^{\text {th }}$ Heru Maulana \\ Mathematics Department, Faculty of \\ Mathematics and Sciences \\ Universitas Negeri Padang \\ Padang, Indonesia \\ herumaulana@fmipa.unp.ac.id
}

\author{
$3^{\text {rd }}$ Meira Parma Dewi \\ Mathematics Department, Faculty of \\ Mathematics and Sciences \\ Universitas Negeri Padang \\ Padang, Indonesia \\ meira.pd@fmipa.unp.ac.id
}

\begin{abstract}
Nowadays, the rapid development of technology into mobile phones has changed the lifestyle for humans. In addition, being a country that became a mobile phone users, Indonesia is also noted as a country with high internet usage. But this is not in line with the utilization of the use of mobile phones, especially in the field of education. As a descriptive development research, in this research will be built an android application that can be used in e-learning process. Then, this application will be piloted/experimented on Actuarial course to observe its practicability and effectivity.
\end{abstract}

\section{Keywords-Android Application, Actuarial Course}

\section{INTRODUCTION}

This The rapid development of technology has influenced human lifestyles. One example is the development of technology on mobile phones that has changed the mobile phone. This can be seen from the use of mobile phones in various human interests, such as in business / work, vacation, capturing various moments and so forth. This development not only affects adult but also children. Nowadays, kids have been using smartphones before they can even talk.

The survey results of the Association of Indonesian Internet Network Providers (APJII) revealed that more than $50 \%$ of Indonesia's population (132.7 million people out of 256.2 million people) has been connected to the internet and about $98 \%$ of the numbers show that they access the internet through their smartphones .kompas.com). From the data most of the users are using smartphones to visit online stores and social media. Nevertheless, Indonesia is one of the countries with low internet penetration which is the second lowest number after India (Ministry of Communication And Information). Mostly, they use the internet for games, social media and online stores.

Based on the developments, we would like to develop the principle of learning anywhere and anytime (mobile learning) via mobile phones? According to Ally (2009: 1), mobile learning is the delivery of electronic learning materials on mobile computing tools to be accessible from anywhere and anytime. Along with the opinion of Ally by Darmawan (2012: 15) Mobile learning is one of alternative that learning services must be implemented anywhere and anytime. Thus, through mobile learning can be realized learning media and teaching materials that can help students in achieving learning objectives. This is supported by the opinion of Sukiman (2011: 29) that learning media can be used to deliver the message from the sender to the recipient so as to stimulate the ideas, feelings, interests and willingness of learners in such a way that the learning process occurs in order to achieve the learning objectives effectively.

Various studies have been conducted in order to develop a learning that can be implemented anywhere through the android device. Liu and He (2014); Fodor and Covaci (2016) have expanded android apps in order to learn English. According to Liu and He (2014), the effectiveness and results will be achieved by someone who learns independently through their application is as good as someone who study in class. While Fodor and Covaci (2016) revealed that the interested in learning English through android is high. While Aseniero et al (2013) build eLearning through android applications in language learning program. Based on Asienaro et al, the use of android applications for eLearning more friendly, reliable, accurate, and faster than the use of eLearning via webpage. Based on the studies that have been done, the author will conduct a research on other parts.

Based on the implementation of mobile learning in the above research, the author wants to develop an android application to build an eLearning on android device through research that will be done. Building the eLearning application will be used Android Studio app and Android SDK, where Android Studio is used to build its application and Android SDK to activate some necessary plug-in. In addition, in this study will also be designed a lesson by utilizing the android application.

The Utilization of this application in learning will be done in Actuarial course. Selection of this course is done with some considerations. Considering the success of previous research on English grammar and programming languages along with actuarial courses containing various formulas that need repetition to understand it. In addition, actuarial course is also a regular subject that be taught by the author. Thus, this article entitled "Development of Actuarial 
E-Learning Based on Android Applications" with the aim is to develop e-learning actuary based on android applications.

\section{THEORY}

\section{A. E-learning}

E-learning is a system or educational concept that manages the use of information technology in teaching and learning process. This understanding is in line with the opinion of Michael (2013: 27) is learning is prepared with the aim of using electronic or computer systems so as to support the learning process. Chandrawati (2010) states Elearning is a process of distance learning by combining principles in the learning process with technology.

According to Pranoto et.el (2009: 309) the utility of E-learning are:

a. The use of E-learning is to support the implementation of the learning process that can improve students absorption of the material being taught.

b. Increasing the active participation of students.

c. Improving students' self-study ability.

d. Improving the quality of educator and training materials.

e. Improving the ability to display information with information technology devices, where with ordinary devices difficult to do.

The advantages of E-learning is to provide flexibility, interactivity, speed, visualization through the various advantages of each media (Sujana, 2005: 253). According to L. Tjokro (2009: 187), E-learning has many advantages, such are:

a. More easily to be absorbed, meaning to use multimedia facilities in the form of images, text, animation, sound, and video.

b. Cheaper, meaning no instructors need, no need for a minimum audience, can be anywhere, anytime, cheap too much.

c. More concise, meaning not much class formality, directly on the subject, subjects as needed.

d. Available 24 hours / day - 7 days / week, meaning that the content of the material depends on the spirit and absorption of students, can be monitored, can be tested by e-test.

The Lack of E-learning according to L. Gavrilova (2006: 354 ) is requiring additional equipment such as computer, monitor, keyboard, etc. Lack of E-learning described by Nursalam (2008: 140) as follows:

a. Lack of interaction between teachers and students or even among the students themselves.

b. The tendency to ignore the academic aspect or social aspect and on the contrary make the growth of business / commercial aspect.

c. The teaching and learning process tends toward training rather than education.

d. Changing the role of the teacher from the original mastering conventional learning techniques, now also learning techniques that use ICT (information, communication, and technology). e. Not all places are available to internet facilities (maybe this is related to the problem of availability of electricity, telephone, or computer).

f. Lack of human resources that dominate the internet.

g. Lack of mastery of computer language.

h. Accessing to adequate computers can be a problem for learners.

i. Learners can be frustrated if they cannot access graphics, images, and videos because of inadequate equipment.

j. Availability of infrastructure that can be met.

k. Information may vary in quality and accuracy so the guidance and questioning features are required.

1. Learners can be felt isolate.

\section{B. Android}

Technology that has become a daily necessity is a cellular phone or mobile phone. The development of technology gives the opportunity to the mobile phone that is smartphone. Smartphones are high-end mobile phones with computer-like functions. The number of smartphone users is increasing every year. Here's the chart of smartphone utilization in Indonesia:

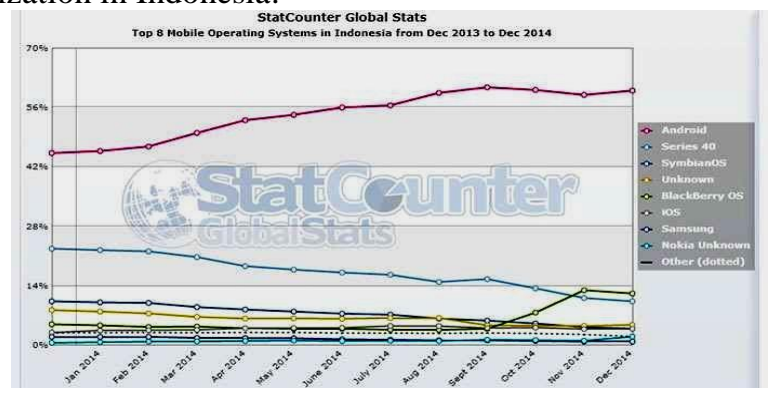

Fig. 1. The Users of Smart phone in Indonesia

Based on the Picture 1, level of smartphone ownership in Indonesia is increasing every year, especially on the use of android smartphone. Almost 59.91\% of Indonesian people use android smartphone from young to old age (http: //id. techinasia.com/).

Sophistication of smartphones can be utilized as an opportunity in the world of education, where smart phones are used as a medium for supporting learning. Learning is expected to be interesting because it feels more interactive, which is equipped with images, sound, animation, and the interactivity of its users.

\section{1) History of Android}

Android is a platform for mobile devices are increasingly popular. In fact, some research companies have named android as a champion of smartphones exceed other platforms, such as Symbian or Applei OS (Mulyana, 2012: $1)$.

Arifianto (2011: 1) is a moving war on the operating system for mobile phones based on linux. Android is software that includes the operating system, middleware, and key of applications (Gandhewar \& Sheikh, 2010: 13). Android is superior to other systems and acts as an emerging 
software platform for mobile devices (Gandhewar \& Sheikh, 2010: 17).

Originally OS android was created by Android Inc.,as a newcomer to software for mobile phones located in Palo Alto, California, USA in October 2003. Its founders consist of three people who are experts in the field of application development, they are Andy Rubin, Rich Miner, and Chris White (http://www.downloadgame androids.com/).Google acquired the company Android Inc. on August 17, 2005 and make it as a subsidiary owned by Google. At Google, a team led by Andy Rubin began to develop a mobile devices platform by using the Linux kernel (http://woocara.blogspot.com/).

Google Inc. built android and make it open (open source) so developers can use android without fees for licenses from Google and can build android without any limitations (Rustianingtyas, 2013: 6).

The operating system was released for the first time on November 5, 2007 by the Android side with the Open Handset Alliance to support the development of open standards on mobile devices (Manzur, 2011: 1).

The Android Software Development Kit (SDK) provides the tools and Application Programing Interface (API) which is required to start in developing applications on android platforms by using java programming languages. The SDK was first released on November 12, 2007 and the developers had the opportunity to provide feedback from the developer of the SDK (Rustianingtyas, 2013: 6).

In September 2008, android began to perform a number of updates gradually or updates to improve the performance of the operating system by adding the new features, fixing bugs on previous android versions. Each version released alphabetically by the name of a dessert, such as cupcake, donut, and so on.

\section{2) Characteristics of Android}

Android has four characteristics, such are:

1) Opened

Android is built as open so that an app can call any of the core functions of the phone such as making calls, sending text messages, using the camera and others. Android is a virtual machine designed specifically to optimize the memory and hardware resources contained within the device. Android is open source, can be freely expanded to incorporate newer, more advanced technologies as they emerge. This platform will continue to build innovative mobile applications.

(2) Equal

Android makes no difference to the main apps of the phone and third-part applications. All applications can be built to have equal access to the capabilities of a phone in providing users with a broad range of services and applications

(3) To solve the Restriction

Android breaks down the barriers to build the new and innovative applications. For example, a developer can combine information obtained from the web with the data on a person's phone such as a user's contact, calendar or geographic location.
(4) The development of application easily and rapidly Android provides the users with extensive access to better applications. Android has a set of tools that can be used to help developers in improving productivity when build the applications that are made

\section{Learning Materials}

According to the National Center for Competency Based Training (2007), understanding of teaching materials is any form of material used to assist teachers or instructors in implementing the learning process. The materials in the form of materials can be either written or unwritten. The views of other experts say that teaching materials are a set of materials that are organized systematically, both written and unwritten, so as to create an environment or atmosphere that allows students to learn. According to Harvest (2001) mengung kapkan that teaching materials are materials or subject matter that is arranged systematically, used teachers and learners in the learning process (Andi, 2011: 16).

According to the Directorate of High School Development (2008: 6), understanding of teaching materials is all forms of materials used to assist teachers in carrying out teaching and learning activities. The material in question can be either written materials or unwritten materials. Based on these definitions, it can be concluded that teaching materials is a learning component used by teachers as learning materials for students and assist teachers in carrying out teaching and learning activities in the classroom.

The types of teaching materials are differentiated over several grouping criteria. According to Koesnandar (2008), the type of teaching materials based on the subject consists of two types: (a) teaching materials deliberately designed for learning, such as books, handouts, LKS and modules; (b) teaching materials that are not designed but can be used for learning, such as clippings, newspapers, movies, commercials or news. Koesnandar also stated that when viewed from the function, the teaching materials that are designed consist of three groups of presentation materials, reference materials, and self-study materials.

Based on the technology used, the Directorate of High School Development (2008: 11) clustered teaching materials into four categories: printed materials such as handouts, books, modules, student activity sheets, brochures, leaflets, wallcharts, pictures, and models / makets. Audio hearing materials (audio) include cassettes, radio, LPs, and audio compact discs. Hearing audiences (audio visual) such as video compact disks, and movies. Interactive multimedia teaching materials such as CAI (Computer Assisted Instruction), interactive multimedia compact disc (CD) and web-based learning materials (web based learning material).

The development of a teaching material should be based on student needs analysis. There are a number of reasons why it is necessary to develop teaching materials, as mentioned by the Directorate of High School Development (2008: 8-9) as follows.

The availability of materials according to the demands of the curriculum, meaning that the learning materials developed must be in accordance with the curriculum. Characteristics of the target, means that the materials developed can be tailored to the characteristics of students as 
a target, the characteristics are meli puti social environment, culture, geography and stages of student development.

The development of teaching materials should be able to answer or solve problems or difficulty in learning. Thus, the development of teaching materials in schools needs to consider the characteristics of students and the needs of students according to the curriculum, which requires the existence of par participation and activation of more students in learning. Development of student activity sheet becomes one of alternative teaching materials that will be useful for students to master certain competencies, because the student activity sheet can help students add information about the material learned through the learning activities in a systematic.

\section{METHODS}

Research method in this research is research design. The reasons for choosing a research design are in line with Edelson (2002): (1) The research design provides a productive perspective on the development of a theory. (2) The research design has a special cirri of results that can be utilized and (3) Direct research design involves researchers in improving mathematics education.

In this study, the product developed is android application that can be utilized to build e-learning. Furthermore, the product is applied / piloted in Actuary class.

Cobb, Confrey, et al (2003 in Bakker 2004) identified five characteristics that were applied in different types of research designs. The first is the goal to develop theories and strategies designed to support learning. The researcher designs an intructional theory for students in integral learning and its application. The second feature is the intervention provided is natural. The methodology makes the researcher is not constrained to improve the design after the experiment is carried out. Third is the feature among which the research design has prospective and reflesi on its components that can not be separated from the experiment. The researcher is confronted with conjectures as a prospective with the actual learning process he or she observes in the reflection section. The fourth feature is the cyclical process of the research design itself. In the characteristics of this cycle the findings and revisions appear as an iterative process. Allegations of learning sometimes do not occur so that alternative allegations can be raised and reexamined. The fifth feature of the research design is that the theory is relatively simple in that it is developed for a specific domain in which the researcher wishes to develop in the Actuary domain.

\section{RESULT AND DISCUSSION}

In accordance with the purpose of this research, which is developing an actuarial e-learning based on android applications. For that, the following presented the results of research that has been done as below.

The form of activities undertaken is to design an application program that will be used in android applications for e-learning. Next make the android application program for e-learning.

The application program that has been generated can be seen in the following figure:

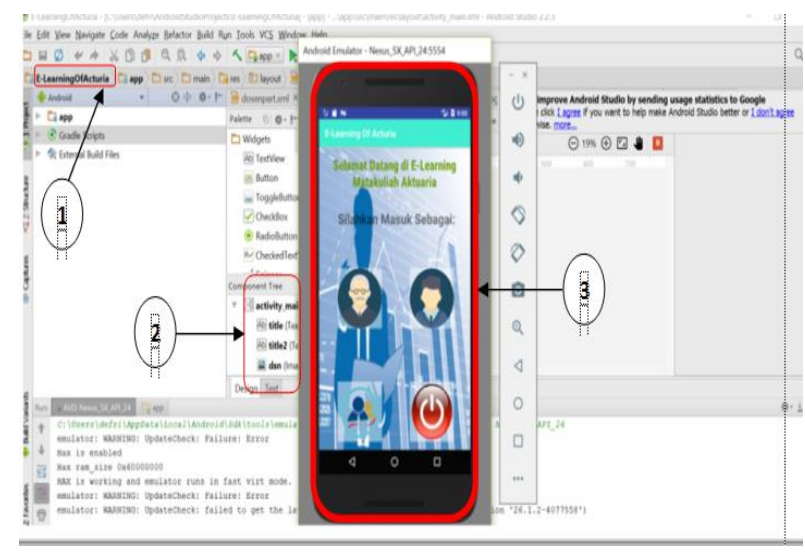

Fig. 2. Program and display of Application

Figure 2 above is a computer screen display of android studio applications, the explanation as follows:

1. Number one (1) shows the file name of the android app for e-learning i.e. "E-learning of Acturia".

2. Number two (2) shows the part where it writes every step of the android application program for e-learning.

3. Number (3) shows the initial appearance on the resulting android program result

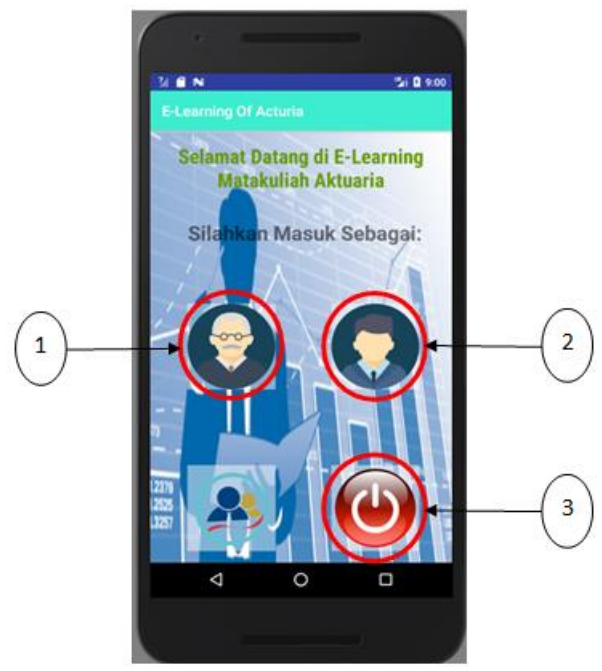

Fig. 3. The preview display of Androidapplication for E-learning

In Figure 3 above there are three buttons that can be used by the user, either by lecturers and students who follow this. The explanation as follows:

1. The one button (1) is used by the lecturer of the course lecturer, and if it is pressed then on the lecturer's android screen will switch to the part like picture 6

2. The two buttons (2) are used by students of course participants, and if pressed then on the student's android screen will move to the section like picture 8

3. The three button (3) is used to close the android application program for e-learning 


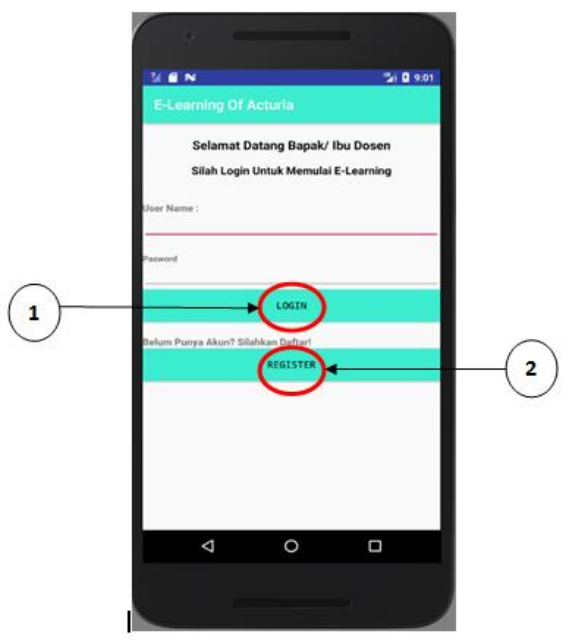

Fig. 4. Menu display for Lectureror Registration

Figure 4 shows the screen where the user of the application as a lecturer of the course to login or register for those who do not already have an account. In the picture shows that:

1. On the button one (1) lecturer pengampu course can go directly to the next section by writing the account name and password and press login as an account already registered. When pressed on the number one button, the lecturer screen android lecturers will switch to the screen as in picture 5 .

2. On the button two (2) the lecturer who will be able to register the course can register first.

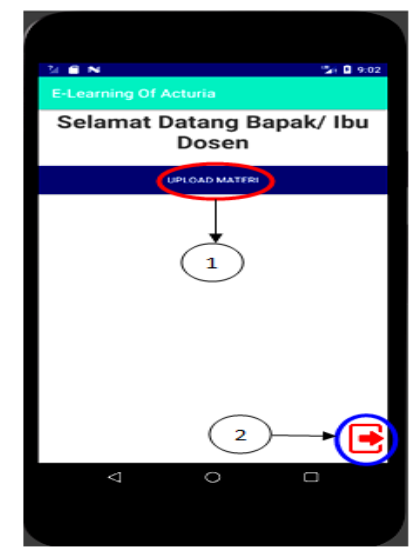

Fig. 5. Menu Button to Upload the Materials

Figure 5 shows a screen containing a menu where lecturers upload the lectures. If the menu at number one (1) is pressed, then the lecturer can enter all the related courses, ranging from RPS (Semester Learning Plan), SAP (Weekly Course Schedule), Teaching Materials, and Tasks. In this case the lecturer can also add other references, such as questions about tasks and other quiz. On the menu number two (2) the lecturer can return to the start menu if press the mark.

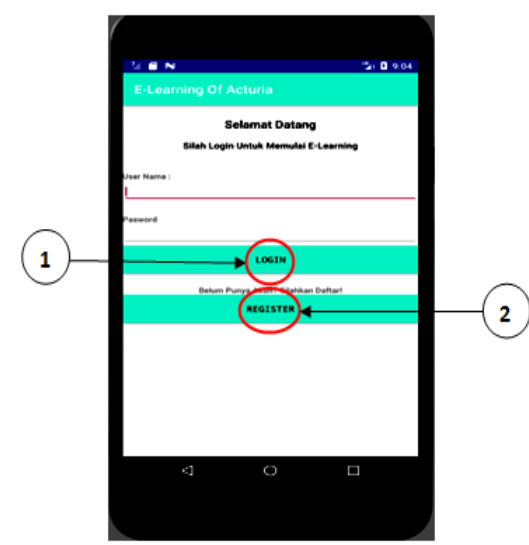

Fig. 6. Menu Display for Students to Login and Register

Figure 6 shows the screen where the application user as a student who took the course to login (login) or register (register) for those who do not already have an account. In the picture shows that:

1. On the button one (1) students who take the course can go directly to the next section by writing the account name and password and press login as registered account. When pressed on the number one button, then the android screen of students who take the course will switch to the screen to do learning activities. Starting from accessing all lecture tools, to interact with lecturers and fellow students.

2. On the button two (2) students who will take the course can register firstly

Furthermore, lecturers and students commence:

\section{Lecturers}

a) Uploading all of the materials in Semester Learning Plan (RPS) form for one semester, Learning Evaluation Unit (SAP) for each meeting, learning materials for one semester, and Task Design of each meeting on android application.

b) To bind the students to discipline in the use of time, lecturers can set the time required by students to access the materials.

c) Especially for the design tasks, lecturers set the deadline of the emergence of questions and upload the answers for students

\section{Students}

a) Downloading all of the materials in Semester Learning Plan (RPS) form for one semester, Learning Evaluation Unit (SAP) of each meeting, Learning Materials for one semester, and Task Design for each meeting in the android application.

b) Due to the limit of downloading time, the students can save the materials and learn it again on other occasion.

c) Especially for the design task, the students do the given problem and then re-upload the tasks that have been made in accordance with the time specified.

To commence the learning process fluently, will be provided a discussion room that allows the students to discuss on certain issues. In this discussion room, students 
and lecturers can interact when and wherever they are. Likewise, students can upload the task files which lecturers can comment directly on each task submitted by the students. Lecturer is expected to be active in accessing the group through the mobile phones.

\section{CONCLUSION}

Based on the progress report above, can conclude as follows:

1. Can be generated an android application program for elearning for lectures Actuarial course in Mathematics Education Program, Mathematics Department, Faculty of Mathematics and Sciences, Universitas Negeri Padang.

2. This application can be used by the Lecturer as a course Actuarial learner.

This application may also be used by students who will take Actuarial course.

\section{REFERENCES}

[1] Allen. Michael, Michael Allen's Guide to E-learning, Canada : John Wiley \& Sons, 2013.

[2] Ardiansyah. Ivan, Eksplorasi Pola Komunikasi dalam Diskusi Menggunakan Moddle pada Perkuliahan Simulasi Pembela-jaran Kimia, Universitas Pendidikan Indonesia, Bandung-Indonesia, 2013.

[3] Arief S. Sadiman, et al., Media Pendidikan, Raja Grafindo Persada: Jakarta, 2007.

[4] Azhar Arsyad, Media Pengajaran, Raja Grafindo Persada: Jakarta, 2000 .
[5] Bakker. A., Design Research in Statistics Education on Sym-bolizing and Computer tools, Freudenthal Institute, Utrecht-the Netherlands, 2004.

[6] Chandrawati. Sri Rahayu, Pemanfaatan E-learning dalam Pembelajaran, No 2 Vol. 8, 2010, http://jurnal.untan.ac.id/.

[7] Edelson. D. C., Design Research: What we learn when we engage in design, Journal of the Learning Sciences, 11, 105 - 121, 2002.

[8] Gravemeijer. K., Local Instruction Theories as Means of Support for Teachers in Reform Mathematics Education, Utrecht : Freudenthatl Institute and De-partment of Educational Research Utrecht UniversityMahir, N. (2009), Conceptual and proce-dural performance of under-graduate students in integration. International Journal of Mathematical Education in Science and Technology, 40(2), 201-211. DOI:10.1080/ 0020 7390802213591, 2004

[9] Gravemeijer. and Cobb. P., Design Research From a Learning Design Perspective. In J, Van Den Akker, K Gravemeijer, S, McKenney, \& N. Nieveen(Eds.), Educational Design Research (pp. $17-51$ ). New York: Routledge, 2006.

[10] L. Tjokro. Sutanto, Presentasi yang Mencekam, Jakarta: Elex Media Komputindo, 2009.

[11] L. Gavrilova. Marina, Computational Science and Its ApplicationsICCSA 2006: 6th International Conference. Glasgow, UK: Springer, 2006

[12] Nursalam dan Ferry Efendi, Pendidikan dalam Keperawatan, Jakarta: Salemba Medika, 2008.

[13] Pranoto. Alvini.dkk., Sains dan Teknologi, Jakarta: PT Gramedia Pustaka Utama, 2009.

[14] Sujana. Janti Gristinawati dan Yuyu Yulia, Perkembangan Perpustakaan di Indonesia, Bogor: IPB Press, 2005.

[15] Tim UNP, Buku Panduan Akademik Universitas Negeri Padang, UNP Press, 2015

[16] ...., Media Pembelajaran, (Jakarta: Departemen Pendidikan Nasional Direktorat Jenderal Pendidikan Dasar dan Menengah Direktorat Tenaga Kependidikan, 2003. 